\begin{tabular}{|c|c|c|c|}
\hline 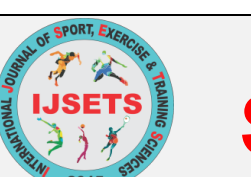 & $\begin{array}{l}\text { uslararası } \\
\text { r, Egzersiz }\end{array}$ & $\begin{array}{l}\text { Antrenman Bilimi } \\
\text { Dergisi }\end{array}$ & 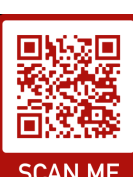 \\
\hline e-ISSN 2149-8229 & Cilt 5, Sayı 4, 214-220, (2019) & Orjina & Makale \\
\hline
\end{tabular}

\title{
The Effect of Respiratory Muscle Training on Aerobic Power and Respiratory Parameters in Swimmers
}

\author{
Yasemin Bağıran ${ }^{1}$, Önder Dağlığ lu², Özgür Bostanc1 ${ }^{3}$
}

Abstract
Aim: The purpose of this study was to investigate the effect of 6 weeks respiratory muscle training on
aerobic power $\left(\mathrm{VO}_{2} \mathrm{max}\right)$ and respiratory parameters in swimmers.
Methods: A total of 20 male swimmers between 18 and 23 years of age were included in the study as
volunteers and randomly divided into two groups as control (n: 10) and control (n: 10) groups.
Respiratory muscle training was applied to the experimental group 5 days a week for 6 weeks.
Respiratory muscle training device (POWER@breathe, UK) and maximal inspiratory pressure (MIP)
value of $30 \%$ of the respiratory muscle training 30 times twice a day was built. Body mass index,
$\mathrm{VO}_{2}$ max, vital capacity (VC), forced vital capacity (FVC), forced expiratory volume (FEV1) and forced
expiratory rate (FEV1/FVC) were measured before and after training. Respiratory parameters were
measured by spirometry. VO $\mathrm{O}_{2}$ max measurements were measured by cardiopulmonary exercise test on
bicycle ergometer. Respiratory muscle strength was used to determine the respiratory pressure gauge. The
data were analyzed in SPSS 22.0 program. Independent Samples T Test was used to assess the
significance between the experimental and control groups. Paired Samples T Test was applied for intra-
group comparisons.
Results: As a result of the statistical analysis, there was a significant difference in the respiratory
parameters of the experimental group (p<0.05). Aerobic power values were not significant (p $>0.05$ ). In
the comparison between groups, there was a significant difference in the values of the respiratory
parameters in favor of the experimental group.
Conclusion: As a result, it can be said that 6 weeks of respiratory muscle training affects the respiratory
parameters positively in swimmers. It is thought that regular respiratory muscle training improves
respiratory parameters.
respiratory parameters.

Article Info

Received:15.11.2019 Accepted:26.12.2019 Online Published:30.12.2019

DOI: $10.18826 /$ useeabd.647449

\section{INTRODUCTION}

Swimming is one of the basic and popular sports in the world. In swimming, swimmers need to increase muscle strength. This is important for swimmers to increase their speed and performance (Maglischo, 2003). The most unique feature of swimming is the water environment. During swimming training, hydrostatic compression around the chest increases, which pushes the chest wall inward when the inspiratory muscles relax. Inspiratory muscles need to be stronger because water pressure resists inspiratory muscle strength (Frangolias \& Rhodes, 1995).

It is easier to overcome the training load for athletes with strong respiratory system (Öncen, 2018). Swimming sport imposes different loads on the respiratory system. Increased breathing frequency during exercise causes the respiratory muscles to use oxygen more. Respiratory muscle training is a resistance training method applied to resistive loading with the aid of device to increase the strength of respiratory muscles (Sheel, 2002). This training method has been tested with different researches in recent years and contradictory results have been reached. These results showed significant improvements in performance after respiratory training, while other studies did not show any significance (Holm et al. 2004).

The cardiovascular and respiratory system acts systemically in the body. It provides a significant increase in maximum oxygen consumption of athletes in increasing intensity training (Akgün, 1993). Maximum oxygen consumption $\left(\mathrm{VO}_{2} \mathrm{max}\right)$ is the maximum amount of oxygen used in the unit time interval. As the amount of oxygen used increases, so does the aerobic capacity. Aerobic capacity is important in the development of sporting performance. (Olbrecht, 2000). Gas analyzer system is the most reliable and valid test method for measuring maximal oxygen consumption. (Wilmore \& Costill, 2004).

\footnotetext{
The role and contributions of each authors as in the section of IJSETS Writing Rules "Criteria for Authorship" is reported that:1. Author: Contributions to the conception or design of the paper, data collection, writing of the paper and final approval of the version to be published paper;2. Author: Data collection, preparation of the paper according to rules of the journal, final approval of the version to be published paper;3. Author: Statistical analysis, interpretation of the data and final approval of the version to be published paper;4. Author: Contributions to the conception or design of the paper and final approval of the version to be published paper. ${ }^{1}$ School of Physical Education and Sports, Gaziantep University, Gaziantep/Turkey, yaseminbagiran@hotmail.com ORCID ID: 0000-0002-2289-1 188 ${ }^{2}$ Corresponding Author: School of Physical Education and Sports, Gaziantep University, Gaziantep/Turkey, daglioglu@hotmail.com ORCID ID: 0000-0002-6213-9855 ${ }^{3}$ Yaşar Doğu Faculty of Sport Sciences, Ondokuz Mayls University, Samsun/Turkey, bostanci@,omu.edu.tr ORCID ID: 0000-0002-7952-1014
} 
The purpose of training in swimmers is to improve race performance and race times. There are very small-time differences between winning and losing. So far, studies have focused on skeletal muscle strength and endurance. Recently, scientists have focused on studies known as respiratory muscle training. This study is important in terms of demonstrating the effect of breathing muscle training on aerobic power and respiration parameters for trainers and athletes engaged in swimming, and in the development of swimming performance and training planning. The aim of this study is to reveal the effect of 6-week respiratory muscle training on aerobic power and respiratory parameters in swimmers and to make recommendations for athlete performance and training periodization.

\section{METHOD}

\section{Participants}

Twenty male swimmers between the ages of 18-23 participated voluntarily as regular swimming training. The participants were randomly divided into two groups as experimental (n: 10) and control group (n: 10). Respiratory muscle training was applied to the experimental group 5 days a week for 6 weeks. Both groups continued their normal swimming training. Subjects were given detailed information about the study 1 week before the respiratory muscle training.

Ethics Committee approval of this study was obtained from Gaziantep University Clinical Research Ethics Committee (Protocol no: 2018/152).

\section{Research Design}

Respiratory muscle training was applied to the experimental group for 6 weeks. The control group did not respiratory muscle training. Both groups continued their normal swimming training. $\mathrm{VO}_{2} \mathrm{max}$, vital capacity (VC), forced vital capacity (FVC), forced expiratory volume (FEV1) and forced expiratory rate (FEV1/FVC \%) were measured before and after training. No special nutrition program was applied to the participants. One week before the application, participants were given detailed information about the working procedure and practices.

\section{Respiratory Muscle Training Protocol}

Experimental group received respiratory muscle training 5 days a week for 6 weeks. They performed 30 repetitive respiratory muscle training twice a day (1-minute rest between repetitions) at $50 \%$ of the MIP value with the respiratory muscle training device. Respiratory muscle training devices are set according to the intensity of the MIP. Saturation values were observed with pulse oximetry to prevent hypoxic conditions.

\section{Data Collection}

\section{Anthropometric Measurements}

The body weight of the subjects was measured with a $0.1 \mathrm{~kg}$ weighing scale and the height was measured with an electronic height meter. Participants were provided with shorts, $t$-shirt and bare feet. Height in cm, body weight was measured in $\mathrm{kg}$ (Fox et al., 1999).

\section{Measurement of Respiratory Muscle Strength}

During the MIP measurement, an electronic respiratory pressure gauge was used. During the measurements, the subject was sitting in the chair. Nasal plugs were used for measurements. The athletes who participated in the study had maximum expiration. In addition, the subject was asked to give maximum inspiration against the closed airway and was asked to continue for 1-3 seconds. Two measurements were taken and the best result was recorded in $\mathrm{cmH}_{2} \mathrm{O}$ (Barğ 1 et al., 2016).

\section{$\mathrm{VO}_{2}$ max Measurement Protocol}

Subjects were subjected to a gradually increasing cardiopulmonary exercise test (Ramp protocol) on a bicycle ergometer (MEC PFT SYSTEMS ERGO). Subjects were informed about the working procedure before the test. During the application, a resting time of 3 minutes was given, followed by 3 minutes of no-load pedaling (warm-up) and then continued with an increase of 25 -watt pedal load in 1 minute. The pedal speed is kept constant at an average of $60-70 \mathrm{rpm}$. During the measurement, the subjects were motivated by voice. At the end of the test, the load was reduced to 25 watts and continued for a further 3 minutes (ATS/ACCP, 2003).

\section{Measurement of respiratory parameters}

Respiratory parameters were measured by M.E.C. Pocket Spiro USB-100 model is used. During the measurements, the subject was allowed to wear sports and comfortable clothes. Subjects were determined to require maximal effort. A separate measuring nozzle was used for each subject. The 
subject was closed with a spigot. Mouthpieces are provided with no gaps in the rim. Subjects are motivated by voice during measurements.

VC measurement: For the test, subjects had normal ventilation three times and then filled the lungs with inspiration at the highest rate and then exhaled the air slowly to the lungs (Günay et al., 2010).

FVC measurement: After the subjects had three normal breaths, the test was terminated by a deep and strong maximal inspiration followed by rapid and deep expiration. With this test FVC, FEV1 and FEV1 / FVC\% values were obtained (Miller el al., 2005).

\section{Statistical analysis}

SPSS (SPSS for Windows, version 22.0, SPSS Inc. Chicago, Illinois, USA) statistical program was used for statistical analysis of the data obtained. Mean and standard deviation values were used as descriptive statistics. The Shapiro-Wilk Test was used to determine whether the data were normally distributed before the statistical procedures were examined. Independent Samples T Test was used to evaluate the significance between the experimental and control groups. Paired Samples T Test was also used for intra-group comparisons. Statistical results were analyzed at $\mathrm{p}<0.05$ significance level.

\section{RESULTS}

Table 1. Pre-test and post-test analysis results of the experimental group

\begin{tabular}{|c|c|c|c|c|}
\hline Variable & $\begin{array}{c}\text { Pre-test (n:10) } \\
\bar{X} \pm \text { SD }\end{array}$ & $\begin{array}{c}\text { Post-test (n:10) } \\
\bar{X} \pm \text { SD }\end{array}$ & $\mathrm{t}$ & $\mathbf{p}$ \\
\hline Age (year) & $20.05 \pm 2.62$ & $20.05 \pm 2.62$ & - & - \\
\hline Height $(\mathrm{cm})$ & $179.42 \pm 0.74$ & $179.42 \pm 0.74$ & - & - \\
\hline Weight (kg) & $71.32 \pm 4.12$ & $71.32 \pm 4.12$ & - & - \\
\hline $\mathrm{VC}(1 \mathrm{t})$ & $4.78 \pm 1.45$ & $5.41 \pm 1.41$ & -2.52 & $0.003 *$ \\
\hline $\mathrm{FVC}(1 \mathrm{t})$ & $4.23 \pm 1.52$ & $4.91 \pm 1.12$ & -2.24 & $0.011 *$ \\
\hline FEV1 (lt) & $3.12 \pm 0.82$ & $3.97 \pm 0.62$ & -3.11 & $0.001 *$ \\
\hline FEV1/FVC (\%) & $90.51 \pm 2.12$ & $92.81 \pm 3.27$ & -2.14 & $0.001 *$ \\
\hline $\mathrm{VO}_{2} \max (\mathrm{ml} / \mathrm{kg} / \mathrm{min})$ & $51.52 \pm 3.48$ & $52.43 \pm 2.82$ & -1.14 & 0.142 \\
\hline
\end{tabular}

In Table 1, the comparison of the pre-test and post-test results of the data obtained after the respiratory muscle training program applied to the experimental group is given. As a result of statistical analysis, respiratory parameters in the experimental group were statistically significant $(p<0.05)$. Aerobic power values were not significant $(\mathrm{p}>0.05)$.

Table 2. Pre-test and post-test analysis results of the control group

\begin{tabular}{lcccc}
\hline Variable & Pre-test (n:10) & Post-test (n:10) & & \\
\hline Age (year) & $\bar{X} \pm$ SD & $\bar{X} \pm$ SSD & t & p \\
Height $(\mathrm{cm})$ & $20.56 \pm 1.16$ & $20.56 \pm 1.16$ & - & - \\
Weight $(\mathrm{kg})$ & $178 \pm 0.32$ & $178 \pm 0.32$ & - & - \\
VC (lt) & $72.24 \pm 5.11$ & $72.24 \pm 5.11$ & - & - \\
FVC (lt) & $4.61 \pm 1.19$ & $4.78 \pm 0.63$ & -1.47 & 0.251 \\
FEV1 (lt) & $4.29 \pm 1.52$ & $4.32 \pm 1.12$ & -1.21 & 0.314 \\
FEV1/FVC (\%) $_{\text {VO }_{2} \text { max (ml/kg/min) }}^{3.52 \pm 0.97}$ & $3.69 \pm 1.32$ & -1.79 & 0.312 \\
\hline
\end{tabular}

Table 2 shows the comparison of the pre-test and post-test results of the control group. No significant difference was observed in the values of the control group ( $p>0.05)$.

Table 3. Comparison of the experimental and control groups

\begin{tabular}{lcccc}
\hline & Experimental Group Difference & Control Group Difference & & \\
Variable & $\bar{X} \pm$ SD & $\bar{X} \pm$ SD & t & p \\
\hline VC (lt) & $-0.63 \pm 0.55$ & $-0.17 \pm 0.11$ & -2.014 & $\mathbf{0 . 0 1 6 *}$ \\
FVC (lt) & $-0.68 \pm 0.11$ & $-0.03 \pm 0.04$ & -2.257 & $\mathbf{0 . 0 0 1 *}$ \\
FEV1 (lt) & $-0.85 \pm 0.37$ & $-0.17 \pm 0.75$ & -1.225 & $\mathbf{0 . 0 0 2 *}$ \\
FEV1/FVC (\%) & $-2.30 \pm 2.18$ & $-0.74 \pm 1.27$ & -1.267 & $\mathbf{0 . 0 0 1 *}$
\end{tabular}




$\begin{array}{lllll}\mathrm{VO}_{2} \mathrm{max}(\mathrm{ml} / \mathrm{kg} / \mathrm{min}) & -0.91 \pm 0.82 & 0.37 \pm 0.64 & 2.253 & \mathbf{0 . 0 1 1 *} \\ * \mathrm{p}<0.05 & & & \end{array}$

The comparison of the measurement results of the respiratory muscle training program applied to the experimental group and control group participating in the study is given in Table 3. Significance was found in $\mathrm{VO}_{2} \mathrm{max}, \mathrm{VC}, \mathrm{FVC}, \mathrm{FEV} 1$ and $\mathrm{FEV1} / \mathrm{FVC} \%$ values in favor of the experimental group $(\mathrm{p}<0.05)$.

\section{DISCUSSION}

Twenty male swimmers between the ages of 18-23 participated in this study. The participants were randomly divided into two groups as experimental (n: 10, age: $20.05 \pm 2.62$ ) and control group (n: 10, age: 20.56 \pm 1.16 ). Respiratory muscle training was applied to the experimental group 5 days a week for 6 weeks. Both groups continued regular swimming training. The age and anthropometric characteristics of the subjects were similar.

\section{Aerobic Power}

In our study, $\mathrm{VO}_{2}$ max values were not significant after the respiratory muscle training program applied to the experimental group $(\mathrm{p}>0.05)$. The $\mathrm{VO}_{2} \max$ values of the control group were not significant $(\mathrm{p}>0.05)$.

$\mathrm{VO}_{2} \mathrm{max}$ is important in increasing sporting efficiency during severe and long activities requiring endurance (Saltin, 2007). It has been observed that during the physical activities, ventilation and the load on the respiratory and circulatory systems accelerate and deepen, while the cardiovascular system becomes more powerful and works faster (Vargo \& Sanderson, 2014; Ardıç, 2014). There are many scientific studies showing that regular training improves $\mathrm{VO}_{2}$ max values (Daglioglu, 2013a; Inan \& Daglioglu, 2013; Gücenmez et al., 2017; İnce \& Dağlıoğlu, 2018).

Romer et al., (2002) found that there was no significant change in $\mathrm{VO}_{2} \mathrm{max}$ values of subjects after respiratory muscle training. Lomax et al., (2011) reported that respiratory muscle training and respiratory muscle warmup (MIP 40\%) on 12 male football players consisting of two groups increased the Yo-Yo test performance compared to the control group. Volianitis et al., (2001) reported that $\mathrm{VO}_{2} \max$ value was higher than experimental group data after respiratory muscle warmup exercise performed with branch-specific general warmup in a study performed on female rowing athletes. Amonette \& Dupler (2002) reported that there is no improvement in $\mathrm{VO}_{2}$ max capacity in a study. In another study performed on young footballers, it was reported that there was no significant change in $\mathrm{VO}_{2}$ max values after four weeks of respiratory muscle training program (Özgider, 2009).

In the literature, contradictory results were obtained in $\mathrm{VO}_{2} \mathrm{max}$ values after respiratory muscle training. The general opinion is that $\mathrm{VO}_{2}$ max values did not change after respiratory muscle training. The development of $\mathrm{VO}_{2}$ max capacity in athletes is achieved through long-term aerobic training. In our study, there was no significant improvement in $\mathrm{VO}_{2}$ max capacity of the subjects after the respiratory muscle training program. The reason for this is thought to be due to the short duration of respiratory muscle training.

\section{Respiratory Parameters}

In the present study, significant differences were found in VC, FVC, FEV1 and FEV1/FVC \% values after the respiratory muscle training program applied to the experimental group $(\mathrm{p}<0.05)$.

During exercise, an increase in respiratory volume occurs to provide the required $\mathrm{O}_{2}$ with increasing metabolic rate. Regular exercise strengthens the respiratory muscles and increases the respiratory volume (Fox et al., 1999). Exercises on the lungs are known to have many positive effects. The highest respiratory capacity among athletes belongs to swimmers (Mehrotra et al., 1998). The performance of the respiratory muscles affects challenging respiratory parameters (thoracic and abdominal muscles). Swimming actively affects the muscles of this region. Because the body performs in the horizontal position. Horizontal posture is beneficial for respiratory muscles. Therefore, swimming provides respiratory development by natural means (Gupta \& Sawane, 2012)

In a study conducted on swimmers, they found that the values of 17 swimmers (FIV1, FEV1) increased after inspiratory and expiratory muscle training compared to the control group (Wells et al., 2005). Respiratory muscle training programs have been reported to increase the performance of elite swimmers by $1 \%$ in studies (Pyne et al., 2004) elite rowers (Lomax \& McConnell, 2003) and cycling athletes (Romer et al., 2002) were found to increase performance. Gosselink et al., (2008) it is 
observed that respiratory muscle training increases respiratory muscle strength. In one study, 28 young fin-swimmers reported significant improvement in inspiratory muscles after respiratory muscle training (Vašíčková et al., 2017).

Many studies have shown that respiratory muscle training has positive effects on respiratory muscles (Lomax \& McConnell, 2009; Kilding et al., 2010). Kubiak Janczaruk (2005) in adolescent swimmers VC, FVC, FEV1 parameters are found to be statistically significant pre-test and post-test values. Doherty \& Dimitrio (1997) in order to compare lung volumes 159 swimmers 130 athletes and 170 sedentary in their study of VC, FVC, FEV1 and FEV1\% parameters compared to the control group was higher than the swimmer and athlete group. There are many studies showing that regular physical activities improve respiratory function (Ozdal et al., 2013; Daglioglu, 2013b; Kalkan \& Daglioglu, 2018; Yılmaz \& Dağlığlu, 2018).

When the literature is examined, it is seen that respiratory parameters values improved after different respiratory muscle training. In our study, respiratory parameters values of the experimental group were improved after respiratory muscle training. This development can be said to be an increase in respiratory muscle strength as a result of respiratory muscle exercise.

\section{CONCLUSION}

As a result, it is considered that 6 -week respiratory muscle training positively affects the respiratory parameters in swimmers. In addition to swimming training, respiratory muscle training may be recommended for the development of high performance and respiratory parameters in swimming.

\section{PRACTICAL APPLICATION}

Respiratory muscle training in swimmers is important in terms of positive development on aerobic power and respiratory parameters and increase in swimming performance. The effectiveness of respiratory muscle training, which is a new approach in training science, needs to be further investigated.

\section{ACKNOWLEDGEMENTS}

This study is a part of Yasemin Bagiran's master thesis. We thank our Department of Physical Education and Sport in University of Gaziantep for their support in our study. The present study was supported by grants from Gaziantep University as scientific research project (BSY.YLT.17.02). There is no conflict of interest between the authors.

\section{REFERENCES}

Akgün, N. (1993). Egzersiz fizyolojisi. Ege Üniversitesi Basımevi, İzmir, 4, 333-43.

American Thoracic Society American College of Chest Physicians. (2003). American Journal of Respiratory and Critical Care Medicine, 167, 211-277.

Amonette, W., Dupler, T. (2002). The effects of respiratory muscle training on $\mathrm{VO}_{2} \mathrm{max}$, the vantilatory thresold and pulmonary function. Journal of Exercise Physiology, 5(2), 29-35.

Ardıç, F. (2014). Egzersiz reçetesi. Türkiye Fiziksel Tip ve Rehabilitasyon Dergisi, 60, 1-8.

Barğı, G., Güçlü, M. B., Arıbaş, Z., Akı, Ş. Z. \& Sucak, G. T. (2016). Inspiratory muscle training in allogeneic hematopoietic stem cell transplantation recipients: a randomized controlled trial. Supportive Care in Cancer, 24(2), 647-59.

Daglioglu, O. (2013a). The effect of 8-week submaximal aerobic exercise on cardiovascular parameters and body composition in young men. International Journal of Academic Research, 5(4), 210-216.

Daglioglu, O. (2013b). The effect of gradually increasing exercise on oxygen consumption and lactate levels in swimmers. Annals of Biological Research, 4(10), 96-102.

Doherty, M., Dimitriou, L. (1997) Comparison of lung volume in Greek swimmers, land based athletes, and sedentary controls using allometrics caling. British journal of sports medicine, 31(4), $337-41$. 
Fox, E. L., Bowers, R. W. \& Foss, M. L. (1999). Beden eğitimi ve sporun fizyolojik temelleri, Bağırgan Yayımevi, (çev: Cerit, M.), Ankara.

Frangolias, D., Rhodes, E. (1995). Maximal andventilatory threshold responses to treadmill and water immersion running. Medicine and Science in Sports andExercise, 27, 1007-1013.

Gosselink, R., Kovacs, L., Ketelaer, P., Carton, H. \& Decramer, M. (2008). Respiratory muscle weakness and respiratory muscle training in severely disabled multiple sclerosiss patients. Archives of physical medicine and rehabilitation, 81(6), 747-51.

Gupta, S. S., Sawane, M. V. (2012). A comparative study of the effects of yoga and swimming on pulmonary functions in sedentary subjects. International journal of yoga, 5(2), 128-33.

Gücenmez, E., Dağlıŏlu, Ö. \& Dağlığlu, T. (2017). The effect of aerobic exercise on oxygen consumption capacities and body composition in football players. Atabesbd, 19(4), 136-147.

Günay, M., Tamer, K. \& Cicioğlu, İ. (2010). Spor fizyolojisi ve performans ölçümü, 2. Bask1. Cicioğlu İ (Ed) Gazi Kitabevi, Ankara, 2, 172-567.

Holm, P., Sattler, A. \& Fregosi, R. (2004). Endurance training of respiratory muscles improves cycling performance in fit young cyclists. BioMed Central physiology, 4(9), 9-23.

Inan, B., Daglioglu, O. (2013). Examination of children's body composition and biomotoric features which attended summer football schools. Turkish Journal of Sport and Exercise, 15(2), 80-87.

İnce, T., Dağlioğlu, O. (2018). The effect of the plyometric training program on sportive performance parameters in young soccer players. Turkish Journal of Sport and Exercise, 20(3), 184-190.

Kalkan, M.K., Daglioglu, O. (2018). The effects of 8-week aerobic training program on respiratory and circulatory parameters of female swimmers between 12-14 years old. Journal of Education and Training Studies, 6(12), 202-207.

Kilding, A. E., Brown, S. \& McConnell, AK. (2010). Inspiratory muscle training improves 100 and $200 \mathrm{~m}$ swimming performance. European journal of applied physiology, 108(3), 505-511.

Kubiak-Janczaruk, E. (2005). Spirometric evaluation of the respiratory system in adolescent swimmers. Annales Academiae Medicae Stetinensis, 51(2), 105-113.

Lomax, M., McConnell, A. K. (2003). Inspiratory muscle fatigue in swimmers after a single $200 \mathrm{~m}$ swim. Journal of sports sciences, 21(8), 659-664.

Lomax, M., McConnell, A. K. (2009). Influence of prior activity (warm-up) and inspiratory muscle training upon between-and within-day reliability of maximal inspiratory pressure measurement. Respiration, 78(2), 197-202.

Lomax, M., Grant, I. \& Corbett, J. (2011). Inspiratory muscle warm-up and inspiratory muscle training: seperate and combined effects on intermittent running to exhaustion. Journal of sports sciences, 29(6), 563-569.

Maglischo, E.W. (2003). Swimming fastest. Champaign, IL: Human Kinetics, 89-123.

Mehrotra, P. K, Varma, N., Tiwari, S. \& Kumar, P. (1998). Pulmonary functions in Indian sportsmen playing different sports. Indian journal of physiology and pharmacology, 42(3), 412-16.

Miller, M.R., Crapo, R., Hankinson, J., Brusasco, V., Burgos, F., Casaburi, R., Coates, A., Enright, P., Grinten, P. M. \& Gustafsson, P., et al. (2005). General considerations for lung function testing. The European respiratory journal, 26, 153-161.

Olbrecht, J. (2000). The science of winning: planning, periodizing and optimizing swim training. Swimshop, Luton, UK. 335(4), 281-283.

Ozdal, M., Daglioglu, O. \& Demir, T. (2013). Effect of aerobic training program on some circulatory and respiratory parameters of field hockey players. International Journal of Academic Research, 5(4), 97-103.

Öncen S. (2018). Antrenman maskesi ile yaratılan normobarik hipoksi ortamda yüksek yoğunluklu interval antrenmanların aerobik ve anaerobik performans bileşenleri üzerine etkisi. Marmara Üniversitesi, Sağglk Bilimleri Enstitüsü, İstanbul.

Özgider C. (2009). Genç futbolcularda dört haftalık solunum kası antrenmanı toparlanma performansını geliştirir fakat solunum fonksiyonlarını ve maksimum oksijen kullanım 
kapasitesini $\left(\mathrm{VO}_{2} \max \right)$ geliştirmez. Orta Doğu Teknik Üniversitesi, Sosyal Bilimler Enstitüsü, Ankara.

Pyne, D., Tresin, C. \& Hopkins, W. (2004). Progression and variability of competitive performance of olympic swimmers. Journal of Sports Sciences, 22(7), 613-620.

Romer, L. M., McConnell, A. K. \& Jones, D.A. (2002). Effects of inspiratory muscle training on timetrial performance in trained cyclists. Journal of Sports Sciences, 20(7), 547-562.

Saltin, B. (2007). Training for anaerobic and aerobic power. In McArdle WD, Katch FI, Katch VL, (eds.). Exercise physiology Energy, Nutrition \& Human Performance (6th ed.) Baltimore: Lippincott Williams \& Wilkins, 469-508.

Sheel, A. (2002). Respiratory muscle training in healthy individuals: Physiological rationale and implications for exercise performance. Sports Medicine, 32(9), 567-581.

Vargo, L., Sanderson, S. (2014). Compression stockings and aerobic exercise: A Meta-Analysis. International Journal of Human Movement and Sports Sciences, 2(4), 68-73.

Vašíčková, J., Neumannová, K. \& Svozil, Z. (2017). The effect of respiratory muscle training on finswimmers' performance. Journal of Sports Science and Medicine, 16, 521-526.

Volianitis, S., McConnell A. K., Koutedakis, Y. \& Jones, D. A. (2001). Specific respiratory warm-up improves rowing performance and exertional dyspnea. Medicine and science in sports and exercise, 33(7), 1189-1193.

Wells, G. D., Plyley, M., Thomas, S., Goodman, L. \& Duffin, J. (2005). Effects of concurrent inspiratory and expiratory muscle training on respiratory and exercise performance in swimmers. European journal of applied physiology, 94(5-6), 527-540.

Wilmore, J. H., Costill, D. L. (2004). Physiology of sport and exercise. (3rd ed.). Champaign, Illinios: Human Kinetics.

Y1lmaz, T., Dağlıŏlu, Ö. (2018). The effect of aerobic training program on cardiopulmonary parameters and oxygen saturation in elite judokas. Turkish Journal of Sport and Exercise, 20(3), 333-337.

\section{CITATION OF THIS ARTICLE}

Bağıran, Y., Dağlığlu, Ö., \& Bostancı, Ö. (2019) The Effect of Respiratory Muscle Training on Aerobic Power and Respiratory Parameters in Swimmers, International Journal of Sport, Exercise \& Training Sciences - IJSETS, 5(4), 214-220. DOI: 10.18826/useeabd.647449 